\title{
European Fashion, Consumption Patterns, and Intercommunal Relations in the 19th-Century Ottoman Istanbul
}

\author{
Anastasia Falierou
}

The contribution of western historiography to the study of fashion and its transformations has been particularly stimulating. Initial forays into the history of clothing, which were largely limited to descriptive or aesthetic analyses, were followed by studies in which several authors have opened new perspectives in this area of research: by analyzing the social dimension of clothing and by emphasizing the interaction between fashion and culture, they have also problematized the shape of the body itself. ${ }^{1}$ In contrast, however, it was not until recently that researchers have become interested in the social history of Ottoman clothing and fashion. ${ }^{2}$

1 See the important works of Roland Barthes, Système de la mode (Paris: 1967); Quentin Bell, Mode et Société: essai sur la sociologie du vêtement (Paris: 1992); Fred Davis, Fashion, Culture and Identity (London: 1992); Joanne Entwistle, The Fashioned Body: Fashion, Dress and Modern Social Theory (Cambridge: 200o); Philippe Perrot, Les dessus et les dessous de la bourgeoisie: une histoire du vêtement au XIX $X^{e}$ siècle (Paris: 1981); Philippe Perrot, Le travail des apparences ou les Transformations du corps féminin XVIII ${ }^{e}-X I X^{e}$ siècle (Paris: 1984); Daniel Roche, La culture des apparences. Une histoire du vêtement XVII ${ }^{e}-X V I I I^{e}$ siècle (Paris: 1989).

2 On Ottoman clothing see Melek Sevüktekin Apak, Filiz Onat Gündüz, and Fatma Öztürk Eray, Osmanlı Dönemi Giyimleri (Istanbul: 1997); Anastasia Falierou, "From the Ottoman Empire to the Turkish Republic: Ottoman Turkish Women's Clothing between Tradition and Modernity", in Constanţa Vintilă-Ghiţulescu (ed.), From Traditional Attire to Modern Dress: Modes of Identification, Modes of Recognition in the Balkans (XVIth-XXth Centuries) (Newcastle: 2011), 175-193; Suraiya Faroqhi and Christoph K. Neumann (eds.), Ottoman Costumes From Textile to Identity, (Istanbul: 2004); Sevgi Gürtuna, "Osmanlı Kadın Giysisi" PhD dissertation, (University of Istanbul:1997); Lale Görünür, Osmanlı Imparatorluğunun Son Döneminden Kadın Giysileri Sadberk Hanım Müzesi Koleksiyonu /Women's Costume of the Late Ottoman Era in the Sadberk Hanım Museum Collection (Istanbul: 2010); Charlotte Jirousek, "The Transition to Mass Fashion System Dress in the Late Ottoman Empire" in Donald Quataert (ed.), Consumption Studies and the History of the Ottoman Empire, 1550-1922. An Introduction (New York: 2000), 201-241; Nancy Micklewright, "Women's Dress in 19th Century Istanbul: Mirror of a Changing Society” PhD dissertation, (University of Pennsylvania: 1986); 
Considering that the history of clothing is an integral part of the history of everyday life, this chapter will analyze clothing as a code for reading and understanding Ottoman society and as a methodological tool that can break the boundaries between micro- and macro-history, and between the private and the public. The genesis of fashion is in and of itself one of the most striking signs of the radical transformation of society. Social changes and changes in fashion go hand in hand. To reflect on the history of clothing and its transformations means not only to go directly to the heart of the social and cultural history of the Ottoman Empire but also to study the process of the transformation of Ottoman society from another point of view, different from the most commonly-envisaged administrative and political perspectives.

The period covered in this chapter is roughly that of the 19th century and extends from the Tanzimat reforms ${ }^{3}$ - when the Ottoman Empire embarked on a program of modernizing reforms along European lines- to the late 19th century. The radical impact of these economic, political, urban, social and cultural changes affected both the private and public spheres.

This chapter centres on the Ottoman capital, Istanbul, which is a natural choice: economically and politically, demographically and spatially, it was unique among Ottoman cities; astride the Bosphorus, it opened to the Sea of Marmara, to the port cities bordering the Aegean, and to the West beyond; last but not least, commercial and cosmopolitan, 19th century Istanbul was greatly impacted by western lifestyles and it remained the principal forum for communication and exchange between the Empire and the outside world. Moreover, the city boasted a strong European presence, particularly in the districts of Galata and Pera, where Levantines, together with non-Muslim populations, played a key role in the modernization of manners by maintaining close relations with Europe, in addition to their well-established diasporas in the Mediterranean and central and western Europe.

The transformative value of clothing is important for several reasons. A profound analysis of fashion juxtaposes, on the one hand, social and professional hierarchies (elites, middle, and lower classes) and, on the other hand, ethnic and religious groups (Muslims of various origins, Greeks, Armenians, Jews and various other European groups). This analysis will focus on the relations

Jennifer Scarce, Women's Costume of the Near and Middle East (London: 1987); Hülya Tezcan, "Fashion at the Ottoman Court", in P-Art, Culture, Antiques 3 (2000), 3-49.

3 The reform period known as Tanzimat began on 3 November 1839 with the issuing of the imperial edict of Gülhane, the manifestation of a deliberate political will to transform and modernize the Ottoman Empire according to the example of European countries. 
between the different ethno-religious communities and the spread of western fashion in Ottoman society.

The evolution of clothing is inseparably linked to the place of both men and women in society and their roles in the public sphere. However, this chapter will limit its scope to the analysis of women's fashion - both upper- and middleclass women-and will describe the transition from traditional to modern clothing by explaining the factors that influenced and, at the same time, differentiated this process of transformation. Several important reasons justify this choice.

Contrary to men, Ottoman women - especially Muslims - led lives withdrawn from public life and were absent from the public sphere. Men and women followed different patterns of evolution. Changes in women's clothing were not subject to political intervention, but rather were influenced by sociopolitical factors, such as the increasing presence of westerners in the city, the flourishing of the foreign - especially French — press, and the strengthening of trade relations with western merchants. In addition, male clothing was characterized by fewer, but more sustainable changes; ${ }^{4}$ women's costume changed quickly, but no change was permanent. Thus, it becomes obvious that in comparison to men's clothing, women's clothing followed an inverse process with respect to the degree and speed of change.

Unlike furniture, clothing penetrates both public and private spheres and thus, signifies the degree of cultural evolution and social change of every society. From this perspective, clothing styles become the visible expression of the penetration of European lifestyles into Ottoman society. ${ }^{5}$

From the length of the stripes to the material of the buttons, in traditional Ottoman society, clothing was meticulously regulated according to economic status, social status, season and circumstance. Numerous sumptuary laws were used as instruments for political, social and economic control by the elites. ${ }^{6}$ Codifying the cuts and materials, they adorned themselves in conspicuous splendour, demarcating the periphery of their social status. ${ }^{7}$ It is therefore

4 For the evolution of male clothing in the Ottoman Empire see Anastasia Falierou, "Réglementer, Identifier, Homogénéiser: Quelques réflexions autour de la modernisation vestimentaire ottomane", in Silvia Marton and Constanţa Vintilă-Ghiţulescu (eds.), Penser le XIXe siècle: nouveaux chantiers de recherche (Iași: 2013), 273-293.

5 Jirousek, "The Transition to Mass Fashion System", 207-208.

6 Donald Quataert, "Clothing Laws, the State and Society in the Ottoman Empire, 1720-1829", International Journal of Middle Eastern Studies 29 (1997), 403-425; Stanford J. Shaw, The Jews of the Ottoman Empire and the Turkish Republic (New York: 1991), 78-79 and Fehmi Yllmaz, "Osmanlı-Gayrimüslim Kiyafet Kanunu", Tombak 32, 2000: 22-26.

7 Jirousek, “The Transition to Mass Fashion System”, 206, 225-228. 
hardly surprising that the immobility in the distribution of clothing signs corresponds to the immobility of the social structures. ${ }^{8}$

The Tanzimat reforms (1839-1876) aimed to bring western ideas and lifestyles to the Ottomans. Throughout the 19th century, western goods, such as cosmetics, furniture, clothing and so on, were bought and used by the Ottoman upper classes. Beyoğlu came to resemble the corresponding areas of cities in western Europe. All the fashionable restaurants, cafes, nightclubs and department stores, such as Karlman, Baker, Madame Vapillon etc., also flourished in Beyoğlu. Non-Muslim as well as Levantine citizens of Istanbul were instrumental in modernizing attitudes and preferences. In almost every respect, the Ottoman way of making clothes was transformed into western methods of garment design and construction.

\section{Tracing Patterns of Transformation in Ottoman Women's Clothing}

An in-depth analysis of the diffusion of European fashion in Ottoman society must be examined through the double prism of class and ethno-religious community. Thus, several questions must be addressed.

First, did Muslim women belonging to different social classes adopt European fashion? Second, does the adoption of European fashion adhere to social more than ethno-religious criteria? In this process of diffusion, what was the role of non-Muslim communities? And, if they played a role, can shared spaces of communication between different millets be delineated in terms of class? These are the questions that this chapter proposes to answer.

A detailed look at Turkish Muslim dress under the influence of European fashion and imperial reform is expected to shed light on the aforementioned questions. ${ }^{9}$ At the beginning of the 19th century, two different modes of dress prevailed in the Ottoman capital. On the one hand, there was the traditional mode of dress ${ }^{10}$ known as alaturca and, on the other hand, the European one known as alafranga. In traditional Ottoman society, Muslim women's costume consisted of a number of layers: baggy trousers (şalvar), along-sleeved, collarless chemise made of cotton or transparent silk reaching down to the ankles (gömlek), and an entari, an ankle-length robe worn over the şalvar and the

8 Ibid., 204.

9 For a detailed analysis of the transformation of Ottoman women's clothing see Anastasia Falierou, "Ottoman Turkish Women's Clothing", 175-193.

10 For the traditional mode of dress see Görünür, Kadın Giysileri, 18 and Jirousek, "The Transition to Mass Fashion System", 210-218. 
gömlek, buttoned or open at the front and tied with a belt (kuşak or kemer). Over the entari Muslim women typically wore a variety of garments, such as the hirka, ${ }^{11}$ a wool cardigan, the cepken, ${ }^{12}$ a long-sleeved bolero that reached to the waist, and the kaftan, worn as a second entari and usually decorated with fur. The fabrics and embroidery on the various garments depended mainly on Muslim women's social class and economic situation.

The entari was considered the most essential indoor garment of Muslim women. Initially, the entari consisted of one single piece. However, in the early 19th century, when the first manifestations of western influence in dress appeared, the entari changed remarkably: it became longer, thus its hem scraped the ground, its sleeves had openings up to the elbows, and it flared down to the fingertips. It was during this period that two new types of entari emerged, the üçetek and dörtetek, whose main features were three or four small openings at the waist. Indeed, the transformation of this garment was so drastic that by the middle of the 19th century, the ikietek entari appeared in the form of a dress, slit on both sides and closed at the front, soon to be followed by the popular biretek entari, a dress without a front opening or side slits. ${ }^{13}$

In outdoor social interactions, women wore the ferace, a long full coat with a square collar, covering the whole body and falling all the way to the ground, and the yaşmak (yashmak), a veil made of fine white muslin. ${ }^{14}$ The yaşmak was separated into two parts, top and bottom, which were tied behind the head leaving a gap at eye level. The ferace was principally made of wool in the winter and silk in the summer. Initially, feraces were plain-coloured and the colour of choice was often dark blue. However, young well-off ladies preferred light-coloured feraces, decorated with cruciform motifs, ribbons, and tulles. The ferace was an important indicator of social origin and its colour and ornaments indicated the social class to which a woman belonged. Under the influence of European fashion, the neck of the ferace widened and acquired rich decorations, ${ }^{15}$ while accessories, such as the parasol, started to complement a woman's external appearance.

Authorities, however, controlled the external appearance of women. Strict rules imposed the shape, colour, and decoration of the ferace, which sometimes verged on the extravagant, and many decrees were passed aiming to

\footnotetext{
11 Reşad Ekrem Koçu, Türk Giyim, Kuşam ve Süsleme Sözlüğ̈̈ (Ankara: 1967), 129-130.

12 Koçu, Giyim, Kuşam Sözlüğ̈̈, 51-52.

13 Görünür, Kadın Giysileri, 51.

14 Koçu, Giyim, Kuşam Sözlüğ̈̈, 240-241.

15 Ibid., 108-111.
} 
reinforce morality, social discipline, and order. ${ }^{16}$ In several cases, new styles in women's clothing were perceived as a deviation from the norm, and such deviation was punished rigidly. Ottoman sources reveal that alterations in dressing styles and more particularly, in Muslim women's costume date from before the 19th century. ${ }^{17}$ However, the rate of change in the 17 th and 18 th centuries was very slow with changes limited to subtle alterations in the shape of garments or in the details of the accessories. ${ }^{18}$

While the Ottomans had developed diplomatic and commercial relations with the West from the 16th century onwards, it was only during the 19th century-especially after the Ottoman-British commercial treaty of 1838 - that the European presence in Istanbul became intrusive. Thus, the number of Europeans - soldiers, diplomats, tourists, artists, etc. - visiting the Ottoman capital had rapidly increased and a great number of manufactured goods imported from abroad, including novelties such as house furniture, decorative items, and clothing, could be found on the Ottoman market. ${ }^{19}$

Arguably, objects produced by a society express its values and the adoption of such objects by another society—in our case the Ottomans—often reflects the desire to identify similar values in this society. From this point of view, the study of dress styles goes far beyond a simple analysis of garments, fabrics, and colours. In fact, such a study has a deep symbolic dimension ${ }^{20}$ because it shows how people see themselves. Dress styles and fashion are undeniably the most visible indicators of change in a society and, in this particular instance, they are also an indication of westernization.

The adoption of European fashion did not take place at the same rate among women of all ethno-religious communities or social classes. Some women-especially members of the imperial harem, wives and daughters of high-ranked Ottoman bureaucrats and rich merchants-could afford fashionable and expensive clothing, while others simply could not. By the mid-183os, European fashion seemed to have penetrated the imperial harem and Pardoe,

16 Betül İpșirli Argit, "An Evaluation of the Tulip Period and the Period of Selim III in the Light of Clothing Regulations", Osmanlı Araștırmaları 24 (2004), 11-28; Quataert, "Clothing Laws", 407-412; Nora Şeni, "Ville ottomane et représentation du corps féminin”, Les Temps Modernes (1984), 66-95.

17 Jirousek, “The Transition to Mass Fashion System”, 218.

18 Görünür, Kadın Giysileri, 14.

19 Fatma Müge Göçek, Rise of the Bourgeoisie, Demise of Empire Ottoman Westernization and Social Change (New York and Oxford: 1996), 97-107.

$20 \quad$ Faroqhi and Neumann (eds.), Ottoman Costumes, $16-17$. 
a British traveller who visited the Ottoman capital, noted that the costume of a "harem favourite" was an odd mixture of European and oriental garments:

She wore trousers of pale blue cotton followed with yellow; and an enteri of light green stripped with white and edged with a fringe of pink floss silk; while, her jacket, which was the production of a Parisian dress-maker, was of dove-colored satin, thickly wadded, and furnished with a deep cape, and a pair of immense sleeves, fastened at the wrists with diamond studs. $^{21}$

According to various sources, European clothing expanded to non-Muslim communities during the same period. Due to their close relations with the West, the Greeks and the Armenians were the first to be influenced. Already in 1835, many Armenians had started to abandon their national costume by adopting the "Frankish dress". A similar situation also prevailed among Greek women, who "had mingled the Greek and European costumes into a heterogeneous mass".22 These descriptions reveal that in this early stage of transformation in clothing, women's costumes were characterized by confusion, as no particular fashion prevailed. The effort to combine traditional and European fashion often resulted in rather amusing, heterogeneous results, a feature of the fashion of non-Muslim communities which lasted until the late 1850 s.

The rate of change among Muslim women decreased as they progressively adopted European fashion; in 1837, the harem favourite adopted the European jacket while in the early 1850 os Muslim women were accustomed to western accessories such as parasols and gloves. ${ }^{23}$

Mrs. Edmund Hornby, the wife of a British official, spent three years in the Ottoman capital and her testimony concerning the appearance of a 12-year-old pasha's daughter in 1855 is revealing:

The dress and trousers are of a thick kind of gauze, of pale salmon-color, and sprigged with silver. A green velvet cap, beautifully embroidered, covers her head, and her hair hangs down her back in numerous plaits ...

21 Julia Pardoe, The City of the Sultan and Domestic Manners of the Turks in 1836 (Philadelphia: 1837), 179; Micklewright, "Women's Dress", 147. For Pardoe and in general, for European women travellers in the Ottoman Empire see Kader Konuk, "Ethnomasquerade in European-Ottoman Encounters", Criticism 46 (2004): 393-414.

22 David Porter, Constantinople and its Environs, in a Series of Letters (New York: 1935), 138.

23 Micklewright, "Women's Dress", 149-150. 
her socks are of embroidered yellow leather, with peaks turning up in front, and she seems very proud of her gray-colored French parasol. ${ }^{24}$

However, during the late 1850 s many wealthy Muslim women wore dresses that were partly traditional and partly European. It is worthwhile mentioning here the example of a young woman's costume in the harem of a pasha:

The gold-embroidered costume, which, comprising a trailing skirt and very ample schalwars hung in exquisite folds as she sat with one foot raised upon the sofa, had been fashioned in the upper part into an imitation of a Frank bodice. This was (at that time) a daring innovation in the usual style of Turkish dress; the hanum was consequently very proud of her stiff, unbending waist. ${ }^{25}$

Although these hybrid outfits were a combination of European style from the waist up, and of traditional style below the waist, in the form of şalvars and the entari, women of the imperial court were very eager to follow European modes of dress especially during Abdülmecid's reign (1839-1861). ${ }^{26} \mathrm{~A}$ primary sign of the influence of European fashion was in the cut and decorative elements of the entari, which lent itself to a variety of European vogues during the second half of the 19th century.

Moreover, Leyla Saz, daughter of the imperial physician İsmail Pasha, who had the honour of being admitted into the sultan's harem, writes in her memoirs that both the sultanes and women of the imperial harem did not hesitate to adopt "daring innovations" such as the décolleté:

The décolleté also appeared at the Serail at first in a moderate fashion: a little bit of the neck and throat uncovered along with the shoulders and arms up to the elbows. Then the décolleté became larger, but the parts that were open were always covered with a light gauze which resulted in a very agreeable impression — almost like the sun being veiled by a transparent mist. ${ }^{27}$

\footnotetext{
24 Micklewright, "Women's Dress", 150.

25 Micklewright, "Women's Dress", 151.

26 Görünür, Kadın Giysileri, 27.

27 Leyla Saz Hanımefendi, The Imperial Harem of the Sultans: Daily Life at the Çırağan Palace During the 19th Century, trans. Thomas Landon (Istanbul: 1999), 184.
} 
In the mid-19th century, another "innovative article" showed up in the wardrobes of Sultan Abdülmecid I's harem: the corset, a cosmetic accessory which shaped the female body into the desired figure and thus, made women of the imperial court feel more desirable. ${ }^{28}$

The increasing number of foreign diplomats, travellers, and officials, who visited the Ottoman capital with their families during the Crimean War (18541856), played a crucial role in the consumption patterns of the Ottomans. The Malakof style ${ }^{29}$ was in vogue and the use of crinoline ${ }^{30}$ became widespread. The diffusion of western fashion in the Ottoman capital cannot be studied without reference to the art of tailoring. The change in clothing habits was linked to the evolution of tailoring and European garments had a more complicated construction compared to the traditional entari or şalvar.

As Ottoman Muslim tailors did not have the necessary knowledge to meet the new fashion requirements, a number of European tailors came to Istanbul during the second half of the 19th century and established their tailoring firms, mainly in Beyoğlu. Home-tailoring flourished during the same period and seamstresses, called modistras, were invited to the houses of wealthy ladies in order to tailor fashionable toilettes.

Elite tailors and dressmakers visited European capitals such as London, Paris, and Vienna to get acquainted with the latest fashions. Even though wardrobes were renewed every season, only a few privileged individuals were able to follow the latest fashions by purchasing original garments. Those who could not afford new garments made alterations to the old ones. In addition to tailors and dressmakers, there were several department stores known as bonmarşe, which opened in Beyoğlu and Galata, selling ready-made clothing for men, women, and children. ${ }^{31}$

The years between 1860 and 1870 marked a turning-point in the history of Ottoman fashion. By the middle of the decade, not only the imperial harem, but also the women of the Muslim elite had adopted European fashions, the latter doing so in order to imitate the palace's lifestyle. Leyla Saz Hanımefendi informs us that in 1867 , when the Sultan Abdülaziz (1861-1876) returned to Istanbul from his journey to Europe, women of the court welcomed him, all dressed according to the latest fashion:

28 Baronne Durand de Fontmagne, Un séjour à l'Ambassade de France sous le Second Empire (Paris: 1902), 289-290; Görünür, Kadın Giysileri, 27-28.

29 Koçu, Giyim, Kuşam Sözlüğ̈̈, 169-17o.

$30 \quad$ Ibid., 204.

31 Uri M. Kupferschmidt, European Department Stores and Middle Eastern Consumers: The Orosdi-Back Saga (Istanbul: 2007). 
The sultanes wore green dresses, quite light, and rimmed with beautiful lace. They had long trains and they wore big diadems along with rather simple necklaces. The older kalfas also wore green dresses, some plain, some striped and some even with polka dots. The youngest girls wore light green dresses mixed with white and some wore white dresses, trimmed with green, along with small flowered patterns or small green ribbons. At that period, the young ladies and young girls had completely abandoned the old dresses with three tails or trains and the baggy pants underneath; fashion now demanded skirts with a single train which was caught up and attached to the belt - there were now petticoats instead of şalvars or baggy pants previously worn. The headdresses had also changed with the times and now usually matched the costumes. ${ }^{32}$

Moreover, several testimonies attest that the pace of adoption of new fashion by the women of the imperial court accelerated when members of other royal families visited Istanbul. ${ }^{33}$ A good example is Empress Eugenie's visit. According to Zeyneb Hanoum, the French empress's visit provoked a veritable revolution in the sultan's harem as "there was a craze for everything French". ${ }^{34}$ Women of the imperial harem tried to imitate the Empress's dress and hairstyles because they thought that she had entranced their master, the Sultan Abdülaziz, thanks to her elegant appearance:

It was after the visit of the Empress Eugénie that women of the palace and the wives of the high functionaries copied as nearly as they could the appearance of the beautiful Empress. They divided their hair in the middle, and spent hours in making little bunches of curls. High-heeled shoes replaced the coloured babouches [Turkish slippers with heels]; they even adopted the hideous crinolines, and abandoned forever those charming Oriental garments, the chalvar and the enturi, which they considered symbols of servitude, but which no other fashion has been able to equal in beauty. ${ }^{35}$

\footnotetext{
32 Saz, The Imperial Harem, 212.

33 This is valid not only for the harem favourites but also the Ottoman sultanes and the sultan's mother (Valide Sultan) herself. For example, it is known that the Valide Sultan did her best to be dressed alafranga when two princesses from Egyptian Khedive visited her at Dolmabahçe Palace. Micklewright, "Women's Dress", 152-153.

34 Zeyneb Hanoum, A Turkish Woman's European Impressions (New Jersey: 2004), 98.

35 Zeyneb Hanoum, Impressions, 97-98.
} 
In general, during the second half of the 19th century, consumption and dress styles defined social identity and rank. Thus, Muslim upper-class women attributed great importance to their appearance by seeking out brand-new materials and embroideries of the finest quality. Such was the degree of rivalry among elite women that, according to Leyla Saz, they avoided wearing similar dresses and collected up all the pieces of the remaining material after a dress had been made for fear that other ladies would copy their models! ${ }^{36}$

Soon middle-class Muslim women followed the example of the elites and adopted the new fashions. By the 1870 , upper-class women had already abandoned the traditional costume. Parisian creations, full of elegance and grace, became the norm for Ottoman princesses and women of noble descent who immediately started parading their new dresses. The crinoline was replaced by the pouf, which formed a bustle at the back of the dress. ${ }^{37}$ Dresses had long trains and were often embellished with ribbons, flowers, and plenty of lace. The female appearance was completed by a number of accessories such as parasols, gloves and hats. Only the older and more conservative women, including those arriving in the capital from the provinces, still preferred the traditional embroidered entari, which continued to be used along with European modes of dress. ${ }^{38}$

Outdoor garments were also subject to European influences during this period: the yashmak became more and more transparent, while the ferace flew wide open as ladies walked along. Women's addiction to western fashion and ornamentation provoked the reaction of the more traditional segments of society. Many writers severely criticized the inappropriate dressing of women. For example, Ali Riza Bey commented that veils had become a means of ornamenting women's faces rather than concealing them, ${ }^{39}$ while Basiretçi Ali Efendi argued in 1877 that women's unsuitable attire could have "dangerous religious implications" and demanded the intervention of the police to maintain social order. ${ }^{40}$

During the last decades of the 19th century, the ferace was replaced by the çarşaf, a large cape, covering the female body from head to toe, brought to

36 Saz, The Imperial Harem, 264-265.

37 Nora Şeni, "La mode et le vêtement féminine dans la presse satirique d'Istanbul à la fin du XIX ${ }^{\mathrm{e}}$ siècle" in Natalie Clayer, Alexandre Popovic, and Thierry Zarconne (eds.), Presse turque et presse de Turquie, (Istanbul, Paris: 1992), 202.

38 Görünür, Kadın Giysileri, 29.

39 Ebru Boyar and Kate Fleet, A Social History of Ottoman Istanbul (New York: 2010), 299.

40 Boyar and Fleet, $A$ Social History, 301-302. 
the Ottoman capital by the wife of Suphi Pasha, who was governor of Syria. ${ }^{41}$ Being subject to alterations under the influence of European fashion, the çarşaf was eventually cut in half to become a skirt, then a cape, and finally, part of the European suit. A thick black veil called a peçe covered Muslim women's faces. ${ }^{42}$ The textiles used to make the çarşaf were mainly satin, alpaca, and taffeta. As far as colours were concerned, similar to the ferace, young women preferred light-coloured çarşafs (purple, light green, turquoise, lilac), while older and more conservative women favoured darker colours, such as violet, dark blue, or black. ${ }^{43}$

Overall, European fashion was in high demand among the Muslim elites of the capital during the last two decades of the 19th century and the wives, daughters, and granddaughters of high-ranking Ottoman officials were dressed alafranga ${ }^{44}$ In the columns of women's periodicals of this period, one can find visual examples of the dress models that Ottoman Muslim ladies aspired to wear.

\section{New Consumption Channels and the Fabric of Ethno-confessional Relations}

In the multiethnic and multicultural Ottoman society, the different ethnoreligious communities did not live completely isolated from each other but maintained-especially in the upper echelons-some channels of communication. In this regard, the dramatic transformation of the capital from an oriental to a modern city played an important role. ${ }^{45}$

In the 19th century, Istanbul had a solid infrastructure and an orderly urban fabric. ${ }^{46}$ One of the main objectives of its 19th century reformers was the construction of an effective transportation system, capable of providing the inhabitants of Istanbul easy access to the capital's main meeting-points, connecting neighbourhoods scattered throughout the city, and making communication between the two shores of the Bosphorus possible. ${ }^{47}$ Thus, it becomes

\footnotetext{
41 Musahipzade Celal, Eski İstanbul Yaşayışı (Istanbul: 1946), 133.

42 Koçu, Giyim, Kuşam Sözlüğü, 65 .

43 Ibid., 66.

44 Görünür, Kadın Giysileri, 27; Micklewright, "Women's Dress", 155.

45 Boyar and Fleet, A Social History, 271-327; Zeynep Çelik, The Remaking of Istanbul. Portrait of an Ottoman City in the Nineteenth Century (Berkley: 1993).

46 Çelik, The Remaking of Istanbul, 49-81.

47 Ibid., 82-103.
} 
obvious that communication and mobility were two fundamental principles not only in determining the evolution of clothing, but also in facilitating contact between members of different ethno-religious communities.

There are numerous indications of these points of contact between different communities. Galata and Pera, for example, were two of the preeminent places in the 19th century, vaunting a sophisticated public space which bound the elites of many ethno-religious communities. The words of B. Bareilles in this regard are significant. For him, Pera was "the point where Asia makes contact with Europe, a centre of attraction for the masses who wanted to reach the spiritual life and were no longer rooted in the past. It can even be said that in the last century all the initiatives which have transformed Turkey started from this point." 48

For instance, in Pera, the elites not only frequented clubs, sports associations, and Masonic lodges, but also restaurants, cafes and breweries, and often met at the theatre or opera. ${ }^{49}$ However, these activities were not available to Muslim women, who led lives of isolation. At dances and balls, Turkish Muslim bureaucrats were not accompanied by their wives. In the street, Muslim women circulated in special carriages, protected from prying eyes by a curtain, and only leaving the house for errands.

How then, were these women so informed about the latest fashions? In some cases, men acted as transmitters of knowledge, describing the dresses worn by Christian women. In addition, Muslim women could attend certain events: the Nahum theatre, for example, had a space exclusively for women, where they were able to watch shows.

Furthermore, the press also contributed to the spreading of fashion. Magazines and periodicals, dress model catalogues and advertisements were all available to women who loved fashion. Particularly during the second half of the 19th century, fashion columns started to appear in major foreign language newspapers, such as The Oriental Advisor, whose Thursday edition included a section entitled "Courrier de la Mode." ${ }^{0}$ In many cases, the clothes worn by Muslim women were copied from fashion magazines, which also often published dress patterns. According to Walker, the dress of the wife of a military officer was copied from an edition of Modes Illustrées (Fashion Illustrated). ${ }^{51}$

In addition to major newspapers, the illustrated press also played an important role in the promotion of women's fashion. Many newspapers and

\footnotetext{
48 Bertrand Bareilles, Constantinople: ses cités franques et levantines (Paris: 1918), 45-46.

49 Boyar and Fleet, $A$ Social History, 281.

5o Micklewright, "Women's Dress", 198.

$5^{1} \quad$ Ibid., 198.
} 
periodicals, such as the Hanımlara Mahsus Gazete (Ladies' Own Journal), published patterns and photographs of new styles together with small captions to inform its female readers. ${ }^{52}$

Most newspapers and periodicals published during the second half of the 19th century were printed in Galata or Pera. Educated polyglot Ottomansboth men and women-often read newspapers or periodicals published in diverse languages. For example, if one scrutinizes Bosphoris, a Greek women's periodical published in Istanbul between 1899 and 1907, it is apparent that Ottoman Greek women such as the periodical's editor Cornelia Preveziotou were reading Hanımlara Mahsus Gazete. ${ }^{53}$

However, far from favouring the dominant Ottoman culture, these intercommunal contacts went in both directions. Educational institutions are a good example of social spaces where there was a mutual influence between Muslims and non-Muslims. A look at the school catalogues of the imperial lycée, Galatasaray, reveals many Greeks, Armenians and other nationalities among its students. Conversely, it is also true that members of the Ottoman Muslim upper and middle classes attended communitarian schools. Such is the case of Ayṣe Sıdıka and her sister Emine Behice, who studied at the Zappeion Greek girls' school.

After the Crimean War, the increased presence of foreign women - travellers and residents-in Istanbul constituted another factor in the diffusion of European, and particularly French, fashion in Ottoman society. ${ }^{54}$ Wishing to satisfy their curiosity about the lives of Muslim women in the Ottoman Empire, many female European travellers came to visit the harems. It is no exaggeration to note that, according to available personal accounts, almost every 19thcentury author describes at least one visit to a harem. ${ }^{55}$ While in the early 19th century contacts remained quite limited due to language difficulties and variations, during the second half of the 19th century, communication was much easier because a large number of Muslim women began to learn French, which was seen as the language of modern civilization.

If any sort of communication were possible between European and Muslim women, then the education of children, cooking, and fashion must have

$5^{2}$ For the role of the illustrated Ottoman press in the creation of a consumer culture see Elizabeth B. Frierson, "Cheap and Easy: The Creation of Consumer Culture in Late Ottoman Society" in Consumption Studies, 243-260.

53 This is my own observation; the opposite is also true.

54 Micklewright, "Women's Dress", 196.

55 Several examples of such visits are described by Leyla Görünür and Nancy Micklewright. Görünür, Kadın Giysileri, 17; Micklewright, “Women’s Dress”, 196-197. 
been the main topics of conversation. During the visits of European women travellers, their clothing was inspected in detail: the women of the harem touched their counterparts' dresses to examine the fabrics, lifted their skirts to inspect their stockings and slips, and tried on their hats and coats. When Turkish Muslim women become more familiar with their visitors or wanted to impress them, they opened their wardrobes to them. Mrs. Edmund Hornby had the opportunity, in 1856 , to see the wardrobe of a Muslim woman in her neighbourhood. 56

For their part, the women of the Ottoman court could learn about the latest fashions through the relations they maintained with foreign queens and princesses. Lale Görünür mentions that Nakșidil Sultan, the mother of Selim III (1789-1807), was the cousin of Napoleon's wife, Josephine. The relationship between the two women undoubtedly played a crucial role in the introduction of European dress styles to the Ottoman Empire in the early 19th century. ${ }^{57}$ Moreover, royal visits to the Ottoman palace — as in the case of Empress Eugenie described above-constituted another channel of dissemination of western fashion in the imperial harem..$^{58}$

The women of the court also received visits from Greek, Armenian, and French women, whose husbands dealt with the Sublime Porte in their capacity as, for example, merchants or interpreters. In his memoirs, Georgios Zarifis recounted that when Abdulhamid II (1876-1909) became sultan, he invited Zarifis's aunt, Tereza, to spend a week at the imperial palace in order to learn about the life of the harem. So that she would not be afraid among the many African eunuchs and slaves of different confessions, a friend, Eleni Mavrogenous, daughter of Doctor Spiridon Mavrogenis, accompanied Tereza. Zarifis's memoirs show that the women of the harem initiated young Christian women into the secrets of Ottoman music and cuisine and, in exchange, they asked the girls to perform European dances so as to have an idea of them. Tereza and Eleni danced the polka, waltz and, mazurka, and the court burst into applause at the end of each dance. Zarifis noted in this regard that "such was the thirst of those imprisoned lives to see something new in the monotonous life of the harem that they would not stop begging the dancers to continue their show".59 In addition, the author related that his aunt was able to maintain a friendship with the sultan's two daughters, whom she visited every time she came to the city after her marriage. Thus, through their contacts with

\footnotetext{
56 Micklewright, "Women's Dress", 197.

57 Görünür, Kadın Giysileri, 42.

58 Micklewright, "Women's Dress", 152-154.

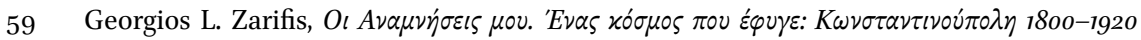
[My Memories. A Lost World: Constantinople, 1800-1920], (Athens: 2002), 169-170.
} 
Christian women - Greek or Armenian — the women of the harem learned of manners and European lifestyles such as dance and fashion. ${ }^{60}$

Moreover, Muslim women learned about European women's customs, habits, and activities-including clothing preferences-from the women mercers who wandered from one harem to the next selling fabrics, jewellery, accessories, cosmetics and other small items. ${ }^{61}$ Available sources describe these women as Greek or Jewish and usually quite elderly. In addition to their trade, women mercers worked as agents for the transmission of information. ${ }^{62}$

Aside from women mercers, foreign house servants and especially English or French governesses also brought European lifestyles and manners directly to the Ottoman private sphere. Employed in the education of the children of the Muslim elite, foreign governesses flooded the Ottoman capital after the Crimean War and late 19th century newspapers were full of advertisements about their qualities and talents. ${ }^{63}$

Finally, wealthy Muslims learned about the latest styles in vogue from the many tailors, dressmakers, and milliners who took up residence in the city beginning with the $1840 s .{ }^{64}$ These professionals played an essential role in transforming the appearances of Ottoman men and women.

In traditional Ottoman society, the role of tailors was relatively small because women were responsible for sewing and making clothes for the whole family. Their contact with tailors or merchant tailors was limited to the ordering of outerwear such as the ferace or the purchase of fabric. However, specialization increased towards the turn of the century when French commercial catalogues, such as Annuaires Orientaux from the 1880 os and 189os, indicate an expansion in the number of trades involved in the clothing business. Indeed, this specialization is the sign of a society in which appearance was highly developed.

Nonetheless, it is difficult to know whether the workshops of tailors and seamstresses were scattered throughout the city or were almost exclusively located in the centre. With only one source, the Annuaires Orientaux, information on this topic is limited. However, the large number of advertisements appearing in newspapers testifies to a high concentration of skilled tailors and

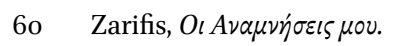

61 Micklewright, "Women's Dress", 196.

62 Ibid., 197-198.

63 Several Muslim writers such as Basiretçi Ali Efendi severely criticized the exclusive use of foreign governesses by upper-class Muslim families. Boyar and Fleet, A Social History, 297-298.

64 Micklewright, “Women's Dress”, 202.
} 
seamstresses in Pera. ${ }^{65}$ Because wealthy women received seamstresses, known as modistralar, in their homes, who sometimes stayed for several days, it is possible to imagine that it was during these times that seamstresses initiated the Muslim elite into the latest fashions.

The Topkapı Palace Museum archive has a large number of letters sent by harem women to tailors, dressmakers, and milliners showing their lively interest in fashionable items as presented in European magazines such as La Saison, Penelope, and l'Elégance Parisienne. These letters also show that some Ottoman princesses sent detailed instructions to master tailors regarding the colours and style of the dresses to be made. ${ }^{66}$

\section{Conclusion}

In conclusion, it is obvious that the introduction of European goodsespecially items of clothing - to Ottoman society created new consumption patterns and practices and led to new forms of identification. By the turn of the 19th century, all the members of the upper classes in Istanbul, regardless of the community to which they belonged, had adopted European fashion. Therefore, at that time, clothing no longer served as an indicator of religion or ethnicity, but of social status. An Ottoman society defined by ethnicity gave way to one delineated by social class and the passage from traditional to modern clothing meant a strengthening of relationships among the different ethno-confessional communities.

Moreover, this chapter argued that contacts between women of different cultures and religions played a crucial role in spreading information and thus, diffusing European fashion and lifestyles in Ottoman society. The extent, however, of interaction between Ottoman Muslim and non-Muslim women varied according to social class. Furthermore, the available evidence demonstrates that mostly Muslim women of the upper class along with, to a certain degree, those of the middle class had established contacts with women of the nonMuslim communities of the Empire as well as with European women travellers. In the end, both European and non-Muslim Ottoman women engaged in transcultural encounters, acting, in general, as mediators for the circulation and dissemination of ideas, and, in particular, as arbiters of fashion tastes and habits in the Ottoman Empire.

65 Charles White, Three Years in Constantinople, or, Domestic Manners of the Turks in 1844, vol. 2 (London: 1845), 54.

66 Hülya Tezcan, "Osmanlı İmparatorluğunun Son Yüzyılında Kadın Kıyafetlerinde Batılılaşma”, Sanat Dünyamız 37, (1988), 45-51. 


\section{Bibliography}

Barthes, Roland, Système de la mode (Paris: 1967).

Bell, Quentin, Mode et société: essai sur la sociologie du vêtement (Paris: 1992).

Bareilles, Bertrand, Constantinople: ses cités franques et levantines (Paris: 1918).

Boyar, Ebru and Kate Fleet, A Social History of Ottoman Istanbul (New York: 2010).

Çelik, Zeynep, The Remaking of Istanbul. Portrait of an Ottoman City in the Nineteenth Century (Berkley: 1993).

Davis, Fred, Fashion, Culture and Identity (Chicago and London: 1992).

Entwistle, Joanne, The Fashioned Body: Fashion, Dress and Modern Social Theory (Cambridge: 2000).

Falierou, Anastasia, "From the Ottoman Empire to the Turkish Republic: Ottoman Turkish Women's Clothing between Tradition and Modernity", in Constanţa VintilăGhiţulescu (ed.), From Traditional Attire to Modern Dress: Modes of Identification, Modes of Recognition in the Balkans (XVIth-XXth Centuries) (Cambridge: 2011), 175-193.

Falierou, Anastasia, "Réglementer, Identifier, Homogénéiser: Quelques réflexions autour de la modernisation vestimentaire ottomane", in Silvia Marton and Constanţa Vintilă-Ghiţulescu (eds.), Penser le XIX ${ }^{e}$ siècle: nouveaux chantiers de recherche (Iași: 2013), 273-293.

Faroqhi Suraiya and Christoph K. Neumann (eds.), Ottoman Costumes From Textile to Identity, (Istanbul: 2004).

Fontmagne, Baronne Durand de, Un séjour à l'Ambassade de France sous le Second Empire (Paris: 1902).

Frierson, Elizabeth B., "Cheap and Easy: The Creation of Consumer Culture in Late Ottoman Society" in Consumption Studies and the History of the Ottoman Empire, 1550-1922 An Introduction, ed. Donald Quataert (NewYork, 2000), 243-260.

Göçek, Fatma Müge, Rise of the Bourgeoisie, Demise of Empire. Ottoman Westernization and Social Change (New York and Oxford: 1996).

Görünür, Lale, Osmanlı Imparatorluğunun Son Döneminden Kadın Giysileri Sadberk Hanım Müzesi Koleksiyonu [Women's Costume of the Late Ottoman Era in the Sadberk Hanım Museum Collection] (Istanbul: 2010).

Gürtuna, Sevgi, "Osmanlı Kadın Giysisi” PhD dissertation, (University of Istanbul: 1997).

Jirousek, Charlotte, "The Transition to Mass Fashion System Dress in the Late Ottoman Empire" in Consumption Studies and the History of the Ottoman Empire, 1550-1922 An Introduction, ed. Donald Quataert (NewYork, 2000), 201-241.

İpșirli-Argit, Betül, "An Evaluation of the Tulip Period and the Period of Selim III in the Light of Clothing Regulations", Osmanlı Araștırmaları 24 (2004), 11-28.

Konuk, Kader, "Ethnomasquerade in European-Ottoman Encounters", Criticism 46 (2004), 393-414.

Koçu, Reşad Ekrem (ed.), Türk Giyim, Kuşam ve Süsleme Sözlüğü (Ankara: 1967). 
Kupferschmidt, Uri M., European Department Stores and Middle Eastern Consumers: The Orosdi-Back Saga (Istanbul: 2007).

Leyla (Saz) Hanımefendi, The Imperial Harem of the Sultans: Daily Life at the Çırağan Palace During the 19th Century (Istanbul: 1999).

Micklewright, Nancy, "Women's Dress in 19th Century Istanbul: Mirror of a Changing Society", PhD dissertation, (University of Pennsylvania: 1986).

Musahipzade Celal, Eski İstanbul Yaşayışı (Istanbul: 1946).

Pardoe, Julia, The City of the Sultan and Domestic Manners of the Turks in 1836 (Philadelphia: 1837).

Perrot, Philippe, Les dessus et les dessous de la bourgeoisie: une histoire du vêtement au $X I X^{e}$ siècle (Paris: 1981).

Perrot, Philippe, Le travail des apparences ou les Transformations du corps féminin $X V I I I^{e}-X I X^{e}$ siècle (Paris: 1984).

Porter, David, Constantinople and its Environs, In a Series of Letters (New York: 1935).

Quataert, Donald, "Clothing Laws, the State and Society in the Ottoman Empire, 17201829", International Journal of Middle Eastern Studies 29 (1997), 403-425.

Roche, Daniel, La culture des apparences. Une histoire du vêtement XVII ${ }^{e}-X V I I I^{e}$ siècle (Paris: 1989).

Scarce, Jennifer, Women's Costume of the Near and Middle East (London: 1987).

Sevüktekin-Apak, Melek, Filiz Onat Gündüz, and Fatma Öztürk Eray, Osmanlı Dönemi Giyimleri (Istanbul: 1997).

Shaw, Stanford J., The Jews of the Ottoman Empire and the Turkish Republic (New York: 1991), 78-79.

Şeni, Nora, "Ville ottomane et représentation du corps féminin", Les Temps Modernes (1984), 66-95.

Şeni, Nora, "La mode et le vêtement féminine dans la presse satirique d'Istanbul à la fin du XIX ${ }^{\mathrm{e}}$ siècle" in Presse turque et presse de Turquie, Natalie Clayer, Alexandre Popovic, and Thierry Zarconne (eds.) (Istanbul, Paris: 1992), 189-209.

Tezcan, Hülya, "Osmanlı İmparatorluğunun Son Yüzyllında Kadın Kıyafetlerinde Batılılaşma", Sanat Dünyamız 37, (1988), 45-51.

Tezcan, Hülya, "Fashion at the Ottoman Court" P-Art, Culture, Antiques 3 (2000), 3-49. White, Charles, Three Years in Constantinople, or, Domestic Manners of the Turks in 1844, vol. 2 (London: 1845).

Yılmaz, Fehmi, "Osmanlı-Gayrimüslim Kıyafet Kanunu”, Tombak 32, 2000, 22-26.

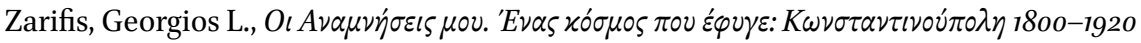

[My Memories. A Lost World: Constantinople, 1800-1920], (Athens: 2002).

Zeyneb Hanoum, A Turkish Woman's European Impressions (New Jersey: 2004). 